University of Nebraska - Lincoln

DigitalCommons@University of Nebraska - Lincoln

Drought Mitigation Center Faculty Publications Drought -- National Drought Mitigation Center

7-3-2002

BEGINNING A NEW ERA OF DROUGHT MONITORING ACROSS

NORTH AMERICA

Jay Lawrimore

Richard R. Heim Jr.

Mark D. Svoboda

Val Swail

Phil J. Englehart

Follow this and additional works at: https://digitalcommons.unl.edu/droughtfacpub

Part of the Climate Commons, Environmental Indicators and Impact Assessment Commons, Environmental Monitoring Commons, Hydrology Commons, Other Earth Sciences Commons, and the Water Resource Management Commons

This Article is brought to you for free and open access by the Drought -- National Drought Mitigation Center at DigitalCommons@University of Nebraska - Lincoln. It has been accepted for inclusion in Drought Mitigation Center Faculty Publications by an authorized administrator of DigitalCommons@University of Nebraska - Lincoln. 


\section{BEGINNING A NEW ERA OF DROUGHT MONITORING ACROSS NORTH AMERICA}

by Jay LaWrimore, Richard R. Heim Jr., Mark Svoboda, Val Swail, and Phil J. Englehart

D rought experts from the United States, Canada, and Mexico met at the National Climatic Data Center in Asheville, North Carolina, for a threeday workshop in late April 2002 to discuss the U.S. Drought Monitor program and to develop a plan for initiating a new program of drought monitoring for North America. Since its inception in 1999, the U.S. Drought Monitor (DM) has been extremely successful in assessing and communicating the state of drought in the United States on a weekly basis. This success, and the recognition that an ongoing comprehensive and integrated drought assessment was needed throughout all three countries, led to a commitment to build a continent-scale program on the model of the DM. The new drought monitoring program is part of a broader effort to improve the monitoring and assessment of climate extremes across the continent through a cooperative effort that was established in 2001 between the three countries.

Drought monitoring has become an integral part of drought planning, preparedness, and mitigation efforts at the national, regional, and local levels. Drought can develop in all regions of the continent, and its effects can be devastating. Since 1980, major droughts and heat waves within the United States alone have resulted in costs exceeding $\$ 100$ billion (inflation adjusted), easily becoming one of the most costly weather-related disasters on the continent during that time (Lott and Ross 2000). The presence of

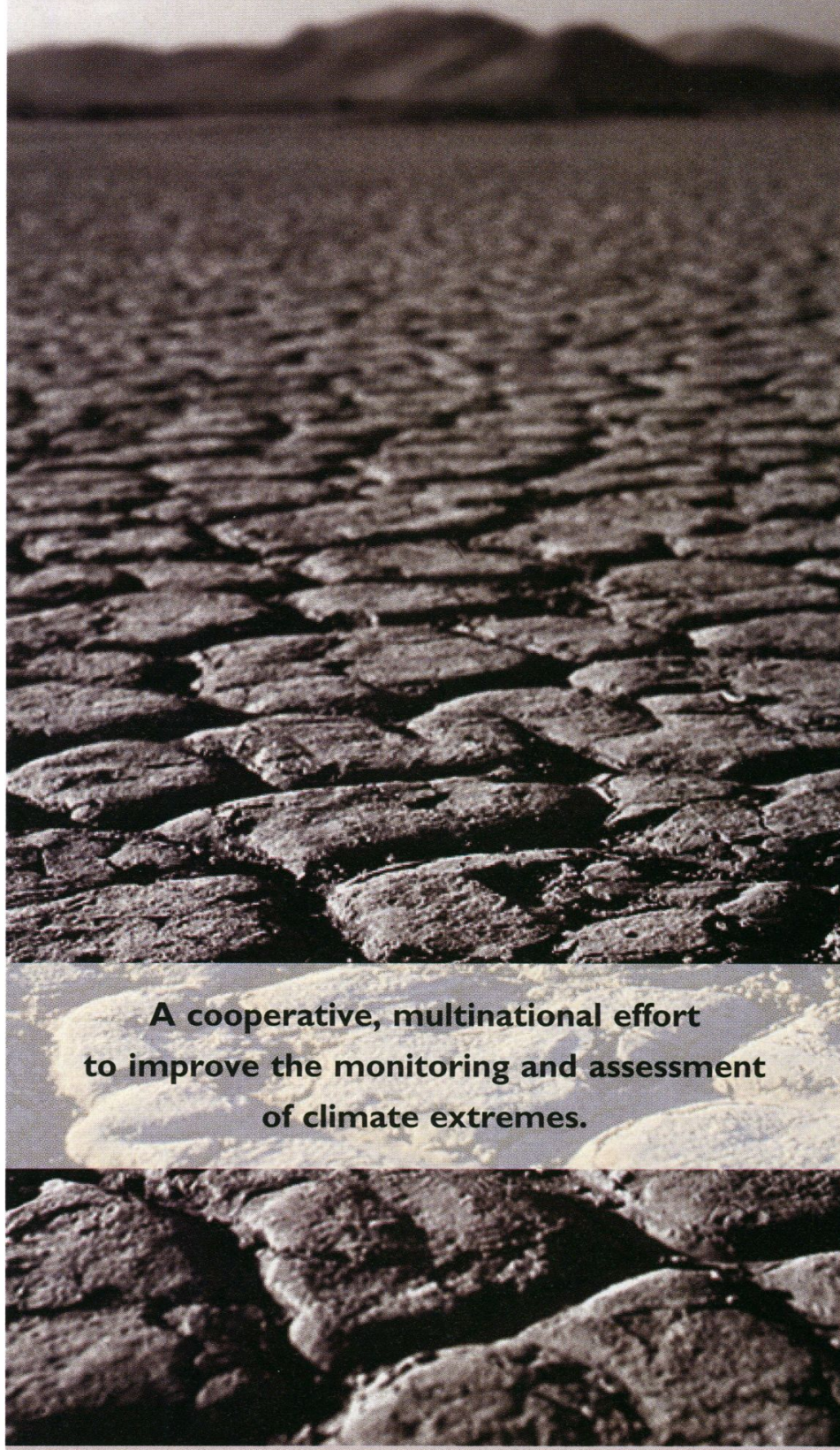

AFFiliationS: LaWrimore AND Heim - National Climatic Data Center, NOAA, Asheville, North Carolina; SvOBODA-National Drought Mitigation Center, Lincoln, Nebraska; SWAlLMeteorological Service of Canada/Climate Research Branch, Toronto, Ontario, Canada; ENGLEHART-Creighton University, Omaha, Nebraska CORRESPONDING AUTHOR: Jay Lawrimore, NOAA NCDC, I5I Patton Ave., Asheville, NC 2880I-500I.

E-mail: Jay.Lawrimore@noaa.gov

In final form 3 July 2002

C2002 American Meteorological Society

severe to extreme drought in approximately $30 \%$ of the United States at the beginning of June 2002, heavy agricultural losses, water restrictions, and numerous 
large wildfires throughout much of the western United States are reminders of the devastation that can result from prolonged precipitation deficits.

But in today's global economy the costs and effects of drought often extend beyond international borders. The continuing drought in much of the southwest United States and a prolonged period of drier than normal conditions in Mexico have led to debates about shared water rights between the two countries. And to the north, the multiyear drought in the Northern Rockies and western Great Plains extends well into the agricultural prairies of Canada, dramatically affecting agricultural productivity in two countries that provide much of the world's food production.

Although all three countries have active climate and drought monitoring programs, until recently there has been only limited cooperation and coordination between the countries' drought experts. Past drought assessments typically have stopped at each country's borders as differences in resources and policy objectives, as well as differing methods for monitoring drought in each country, effectively prevented an integrated view of drought conditions across the continent. The success of the U.S. Drought Monitor (see the preceding article by Svoboda et al.) in providing an integrated assessment of drought for planning and response throughout the United States led to the agreement that the DM would form the basis for the new North America Drought Monitoring program while remaining a separate and distinct entity.

Because of the link between these two monitoring programs, the April workshop provided for open technical discussions and presentations from authors and users of the weekly U.S. drought assessments as well as a review of data collection and monitoring activities in each country and discussions of how an integrated drought monitoring effort for the continent could be best achieved. Primary participants were selected and the necessary steps for implementing the new program were outlined. Other issues included procedural development for ensuring data availability, data quality, and coordination among the continent's drought experts.

Three teams were established to 1) develop continent-scale databases, 2) create product and data displays, and 3) integrate Drought Monitor authors into the monthly monitoring and assessment process. Each team is currently working with the objective of initiating operational monthly drought assessments and dissemination of a North America Drought Monitor (NA-DM) map and accompanying textual discussion by November 2002. Much of the focus of these teams is on developing reasonably consistent definitions of drought as it occurs throughout the continent and creating essential databases with high quality historical records and data that are accessible in near-real time. Also of importance is the development of necessary software that will enable the calculation and display of common drought indices and related statistics that will be used in assessing drought.

The NA-DM map will initially be released as an experimental product. As procedures, analytical techniques, and methods of coordination mature, the monthly assessments will no longer require the label of experimental. The success of this monitoring effort will also help determine if a transition from a monthly to a weekly continent-scale Drought Monitor will be possible at some time in the future. Weekly updates would allow rapidly changing conditions to be continually monitored and more current summaries of drought conditions provided to government and private sector decision makers as well as the public in a manner similar to the current implementation of the U.S. Drought Monitor.

U.S. participants involved in the development and implementation of the North America Drought Monitor include drought experts from the National Oceanic and Atmospheric Administrations's (NOAA's) National Climatic Data Center and Climate Prediction Center, the U.S. Department of Agriculture, and the National Drought Mitigation Center at the University of Nebraska-Lincoln. Others from the United States include representatives from NOAA's Regional Climate Centers and several state climate offices and universities. International participants include representatives from Agriculture and Agrifood Canada, the Meteorological Service of Canada (MSC), and the National Meteorological Service of Mexico [Servicio Meteorologico Nacional $(\mathrm{SMN})]$.

\section{REFERENCES}

Lott, N., and T. Ross, 2000: A Climatology of Recent Extreme Weather and Climate Events, NCDC Technical Report 2000-02, 18 pp. 